\title{
THE TRADITIONS OF JAPANESE CERAMICS
}

Summary: The article focuses on an important topic - the traditions of Japanese ceramics. Its relevance lies in the importance of solving the problem of identifying artworks: whether they are fake or original. Incorrect attribution of an item can lead to severe legal and material consequences and significantly affect the reputation. Differences between the terms "a copy" and "a forgery" with the assessment of positive and negative aspects of falsification are revealed. Highly qualified specialists with certificates and diplomas are required to identify and attribute art. The article shows the main requirements they must have. It also highlights and covers the characteristics and central problem of Western art, describes the ideology of Eurocentrism, according to which Europe, or the West, is the highest stage of human civilization; the rest of the world is considered primitive and undeveloped. A vivid example of an error in identifying a work of art by the Getty Museum - the sculpture Head with Horns and several cases of creating grandiose first-class forgeries in the art of Japanese ceramics are presented in the article. The works of such artists as Kato Tokuro, a ceramic artist whose works have won the highest artistic award in Japan and are widely recognized among collec-

Problems of counterfeiting for museums, private collectors, and galleries are hard to overestimate. According to various estimates, from 30 to $60 \%$ of the international art market is counterfeit. Often, many expert reputations depend on the correct determination of the authenticity of the exhibit. Incorrect attribution of artworks can lead to severe legal and material consequences for one or more parties.

In the course of writing the article, methods of comparative historical analysis and typological description of the considered phenomena were used as well as an axiological method to reveal value orientations given to an individual by art. A specific historical analysis, a description of particular facts with their subsequent theoretical understanding, was also applied. A comparison of philosophical tors and curators of the West, Kagami Shukai, and Kato Koju have been studied. The article describes the Setoceramic tradition and its significance for common cultural art. It was created by the great Kato Shirozaemon and got its name from the name of the city in Japan, famous for its pottery. The article shows the importance of traditional methods in Japanese ceramic art history. Hence the desire of masters to follow ancient patterns and techniques. The article also describes the features and reveals the differences between traditional and Studio ceramics. The characteristics of the Asian approach, which aims to reproduce cultural values in an unchanged form, parallel with the development of progress in other areas, are studied. The article's main task is to teach how to detect an obvious forgery by analyzing genuine ceramic products' characteristic features. For this purpose, significant analysis of the distinctive features of authentic ceramic products is given. Several techniques and methods for determining the authenticity of the exhibit are presented.

Keywords: falsification, copy, Seto ceramic tradition, yellow Seto, Japanese ceramic tradition, forgery, product evaluation.

and aesthetic, cultural, art historical, psychological aspects of this phenomenon was carried out.

Even though the current cultural dominance of the West in third world countries is an integral part and one of the critical aspects of neocolonialism, which at the same time today exists in the so-called multiracial societies of the West, the concept of such dominance was formed long before the emergence of multinational states. Its appearance coincides with the beginning of the New era in the West, when, paradoxically, it became part of the Western "humanistic" concept of world order. Later, this paradox seemed to be resolved, at least on a theoretical level, by Marx with his historical materialism and dialectical theory of liberation; however, the messianic task of the European "humanistic" tradition 
of domesticating the rest of the world is ongoing. The ideology of Eurocentrism, according to which Europe, or the West, is the highest stage of human civilization development, and the rest of the world is considered primitive and undeveloped, sets a hierarchical pyramidal structure of the world, in which both human and natural energy, moves upward and concentrates at the very top of the pyramid.

Western art is popularized around the world as part of ideology according to which art does not depend on the social and economical and political conditions of a people. Art can be created anywhere (that is, in Europe) by a couple of "geniuses", and all other nations of the world will consume it.

There is an obvious problem for art in the West, namely: pure art is prohibited there. Therefore, many works remain unknown since, at the moment of inspiration, the creator of art does not think about tolerance, racial and religious prejudice, and respect for proportionality in gender diversity.

The topic discussed in this article is based on the concepts "a copy" and "a fake" in art, their positive and negative impact on civilization. According to a dictionary, a copy is "a copy of the original, performed by the author or by another artist. A copy may differ from the original in technique and size; however, unlike a replica, it must exactly reproduce the manner and composition of the original" [Dictionary of Visual Arts Terms]. In most cases, works are copied for training (skill acquisition); however, copyright copies for sale are also possible. The purpose of a counterfeit is to gain profit by deception.

Many millennia ago, people took the first steps on the art path since they needed beauty even in the most severe conditions [A.M.Mironov, P. 61].

The ancient Romans were the first creators of countless copies [A.I.Voshchinina, P. 352].

It is worth noting that highly qualified specialists, confirmed by certificates and diplomas, are needed to identify and attribute art. Finding such specialists, especially in some regions of Asia and Oceania, is problematic. Besides, local features of the West's arts and crafts are particular, and this area is quite limited, making identification difficult. It may lead to the acquisition of counterfeits as exhibits by leading museums.

A recent example was observed when the Getty Museum acquired the sculpture Head with Horns, which was first attributed to Gauguin's authorship and, then, to the Polynesian masters. As a result, Polynesian art critics refuted the second version due to the non-specific character of this works for local artistic traditions. The version of Gauguin's authorship was excluded due to the work's correlation with photo sources contemporary to Gauguin. The exact amount of damage suffered by the museum is unknown as the transaction details were not announced. However, according to insider information, the Getty Museum's losses from incorrect identification amounted to \$3-5 million [The Art Newspaper, 2020, p.10].

Further, let us consider similar cases regarding Japanese ceramics.

One of the biggest scandals in the history of attribution of ancient ceramics is associated with Kato Tokuro, a ceramic artist, whose works received the highest artistic awards in Japan and are widely recognized among collectors and curators of the West. In particular, they were presented at exhibitions at the Metropolitan Museum of Art and Seibu Department Store and Christie's auction. [Asobi, 2014, p. 46]. The entire Suisen Togei Memorial Museum in Nagoya is dedicated to Kato's work.

"When you display your work for everyone to see, you receive scathing criticism. That's when you become mature," Kato believed.

Kato Tokuro inherited his family's craft. The skill traditions were passed down from generation to generation of the Tokuro family. Moreover, Tokuro was born and raised in an area especially rich in pottery traditions in Japan - namely, in Seto. The city's name gave the title to the traditional Japanese ceramics since one of the "six ancient kilns" was located there. These six places gave rise to the main traditions of Japanese ceramics.

The tradition of making Seto pottery goes back to the $13^{\text {th }}$ century. Kato Shirozaemon brought the manufacturing technology of this type of ceramics from China and, subsequently, after several unsuccessful attempts to settle in different parts of Japan, founded a ceramic workshop in Seto. The pottery he manufactured received the name Ko-Seto. [Franks, 1880, p. 29].

Kato Shirozaemon became famous despite attempts to make porcelain through stoneware produced at high temperatures, known as Ishi-yaki.

Kato Shirozaemon passed on the tradition of pottery making to his descendants, and his family lived and made ceramics under his name for four generations. The manufacturing tradition of the Seto ceramics was passed down among the craftsmen for several centuries. 


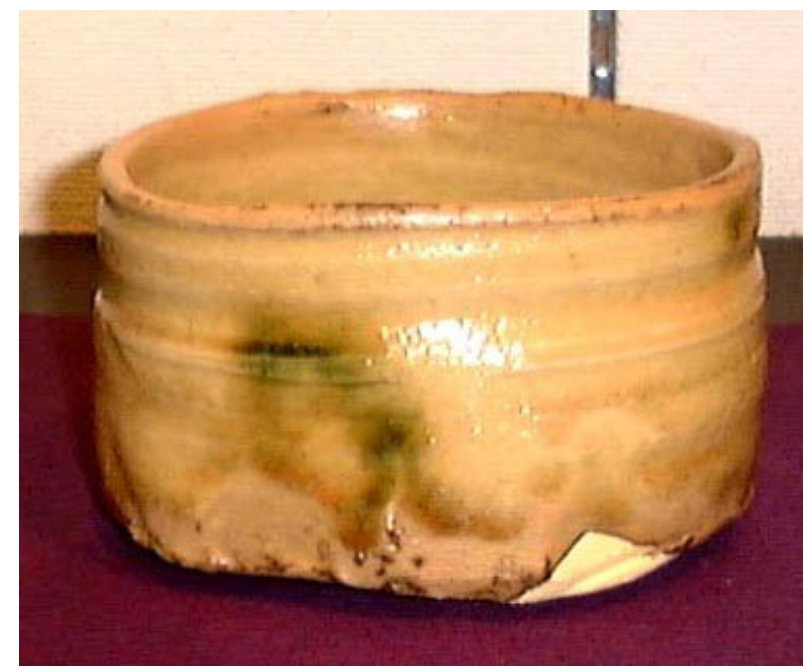

Ki-Seto Chavana. Author: Kagami Shukai. Ceramic. Late 16th century. Ownership: Mino Potter Kato Kozo's home

This type of pottery is named Seto after the area north of Nagoya. The term setomono, "an object from Seto", is synonymous with porcelain in Japanese. However, many types of ceramics, in addition to porcelain, were produced in the Seto region.

The Seto type of ceramics is central to the Japanese tradition of this art form and is actively realized by the Japanese. This is reflected in the name kuniyaki - "national products", often applied to the region's ceramic products. [Seton, 2004].

This region traditionally produces tableware for tea ceremonies, further enhancing Seto's importance for the Japanese ceramic and common cultural tradition.

Produced in the same region, the Ki-seto pottery (yellow seto) is closely related to the tea ceremony (see Appendix 1). The Ki-Seto tradition began in the $15^{\text {th }}$ century by craftsman Huquan who founded the production of Ki-seto - rough dishes with a characteristic yellow tint (see Appendix 1). Most of Ki-Seto pottery was made near Mount Sanage.

According to some classifications, Ki-seto is counted as the Mino ceramics even though the latter was not produced in Seto but in Tajimi-mura (Tajimi) adjacent to the Aichi area, where Seto is located. However, according to the most popular opinion, the city of Seto and its surroundings were the traditional place of the Ki-seto production from the very beginning.

In his book, Yellow Seto, Kato Tokuro put under question this generally accepted theory. He claimed that Ki-seto belongs to the Mino ceramics [Seton, 2004] and, accordingly, was produced in the city of Tajimi [Tokuro, 2020]. In addition, Tokuro criticized

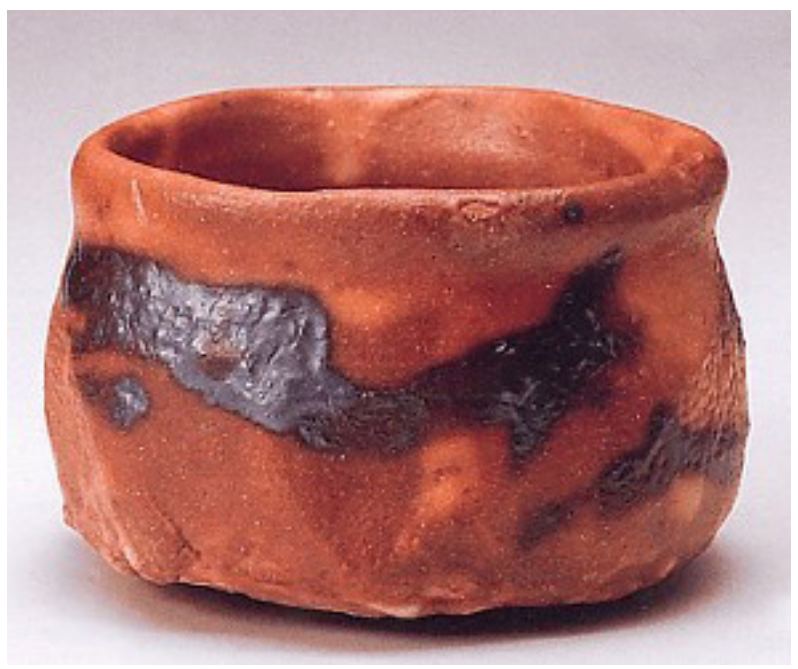

Sake Vessel. Author: Kato Tokuro. Ceramic. 1937

the unfounded reverence for tradition. The book caused a scandal, and the devotees of traditions and nationalists burned many of its copies.

Despite the revolutionary, by Japan's standards in the 1930s, ideas, Kato Tokuro continued to work within the traditional ceramics. Thus, the dish "Nezumi-shino Chavan" made by him was compared with the best pottery of the Monoyama period (late $16^{\text {th }}$ - early $17^{\text {th }}$ centuries) and was considered as a revival of the Shino ceramics [Asobi, 2014, p. 46] manufactured in the Mino region at the end of the $16^{\text {th }}$ century. It is characteristic that, before making this product, for many years, Kato Tokuro had studied ancient samples of the Mino ceramics to be able to reproduce the technology and design accurately.

Kato Tokuro was proud of his ability to create ceramics indistinguishable from ancient designs, even by experts. In 1937, Tokuro made several copies of a sake vessel from the Einin period (1293-1299). According to another version, they were made by his son Okabe Mineo. Later, the potter smashed them and buried them near one of the ancient ceramic kilns. In the early 1960 s, the fragments were found during archaeological excavations. Renowned ceramist Fujio Koyama identified the pieces as a significant cultural value and suggested giving them the official status of Important Cultural Values. It should be noted that Fujio Koyama was friends with Kato Tokura; however, he did not know about his friend's trick. When Kato Tokura confessed to what he did, they were discredited and forced to file resign. As a result of the scandal, Tokuro's reputation was destroyed and never fully recovered from the damage suffered. Thus, even when Tokuro's prod- 


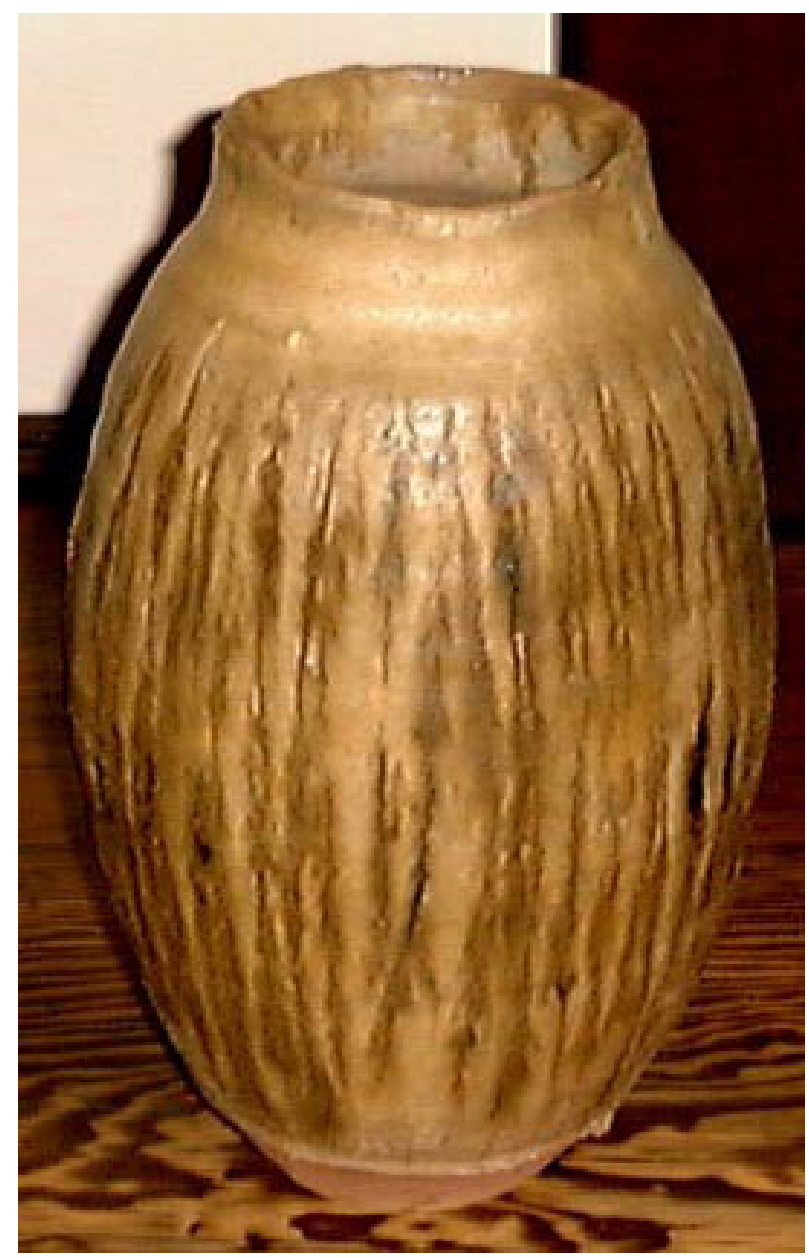

Vase (tsubo pot) Ki-Seto. Author: Kato Kozo. Late 16th century. Ceramic Ownership: Mino Potter Kato Kozo's home

ucts (see Appendix 2) were counted as a national treasure, the national treasure status was not given to Tokuro himself as was the case with the most honored eminent Japanese ceramics artists of the 20-21 st centuries.

Thus, the high importance of traditional techniques in Japanese ceramic art history can be noted. Hence the desire of the masters to follow the old patterns and traditional techniques. This trend can be traced among representatives of families for centuries specializing in the manufacture of ceramics. From here, there are several main consequences.

First, there is incessancy and practical invariability of tradition over the centuries, a high degree of continuity of the artistic tradition [Seton, 2004]. In contrast to the so-called studio ceramics, where innovation and an emphasis on the author's personality were welcomed, traditional ceramics, especially made in villages and ancient urban centers of production, were manufactured with a thorough observance of the preserved traditional technologies
[Seton, 2004]. If some technology is lost, the masters are ready to spend considerable time and effort studying and recovering the technology in its traditional form. It is characteristic that the masters specializing in fake ceramics constitute a significant part of dealers selling ceramics smithers of the imperial period in China. [An Appreciation of Porcelain in Four Objects, 2018]

Thus, tradition is valued above innovation, and antiquity and the maximum permanence of technology is a value in itself. This feature is consistent with the general focus of the Asian approach to reproducing cultural property, in a broad sense, without changing anything, in parallel with progress in other areas of activity.

As many Asian arts and crafts, Japanese ceramics are characterized by the lack of emphasis on the artist's personality. On the contrary, tradition and anonymity are emphasized [Seton, 2004]. A seal, a signature, or individual strokes, which are a kind of author's signature, cannot always be found on Japanese or Chinese masters' works. The attitude of Asian masters to authorship often differs from the one characteristic of more individualistic cultures. In Japan, including in Seto, rural ceramics are traditionally anonymous [Asobi, 2014, p. 105].

Often, artists, working within the tradition, lack the desire to designate their authorship. A similar deindividualization of works of art creates additional complexity of identification and attribution. The subjectivity of expert opinion and, often, lack of the ability to make attribution with $100 \%$ accuracy constitutes the other side of the problem.

Moreover, difficulties arise when evaluating products since the value varies greatly depending on the authorship. Hence, collectors, auction houses, and private galleries face additional challenges when assessing works of art with designated authorship. Wrong value estimate, category, and/or authorship of ceramics may result in compensation, lawsuits, reputational consequences, reduced trust in dealers, expert appraisers, and individual collectors exhibiting artworks for sale or providing them for temporary expositions.

Another consequence of a thorough adherence to tradition is the increased possibility of counterfeiting. Counterfeits in Asia do not necessarily have a practical character. Thus, Christie's auction experts point out that, often, forgeries are created out of respect for traditions. [Collecting Guide, 2020] 
When Chinese billionaire and collector Liu Yiqian bought $15^{\text {th }}$ century Chicken Bowl for a record $\$ 36$ million at Sotheby's auction, his wife Wang Wei, who works as a curator at the museum, received 10,000 high-quality copies of the masterpiece as a gift from Xiang Yuanhua, an owner of a workshop in Jingdezhen city, province Jiangxi, specializing in ceramics counterfeiting [An Appreciation of Porcelain in Four Objects, 2019]

Ancient works are considered unsurpassed in quality and technique of execution. Many masters carefully study the smallest nuances of ancient ceramics; antiquity and tradition give the product a particular selling value. In this way, high-quality imitations will inevitably appear on the market of antique objects.

In China, for instance, there are a significant number of workshops specializing in high-quality counterfeits of Chinese porcelain of the Ming and Qing dynasties [Pomfret, 2008]. For example, counterfeiting Ming and Qing ceramics is one of the specializations of ceramic workshops in Jingdezhen City, Jiangxi Province. Since large auctions use provenance (the origin and continuity of ownership of a work of art from its creation to admission to the auction) as one of the main criteria for determining authenticity, often, such items enter the market through small auctions, which carry out checks less thoroughly [Chao, n.d.].

Subsequently, after passing through the hands of a row of collectors and experts, such ceramics can get into larger auction houses, large and respected private collections, and even to exhibitions [F.R. What Makes a Work of Art Valuable, 2017].

Moreover, Asia has a long tradition of counterfeiting ceramics. For example, the ceramics of the Ming dynasty (1368-1644) have been highly valued by collectors for centuries. As a result, masters counterfeited both the pottery itself and the Ming period seals on it already during the Qing dynasty (1644-1912) [An Appreciation of Porcelain in Four Objects, 2018].

Thus, such works can be challenging to distinguish from the originals of the period and/or of the master not only for buyers and collectors but also for appraisers, experts in decorative and applied art of a certain period, gallery owners, and others.

The following methods are used to determine the authenticity of an exhibit: verification of provenance, comparison of ceramic samples by weight and tactile indicators, shade and glaze analysis, characteris-

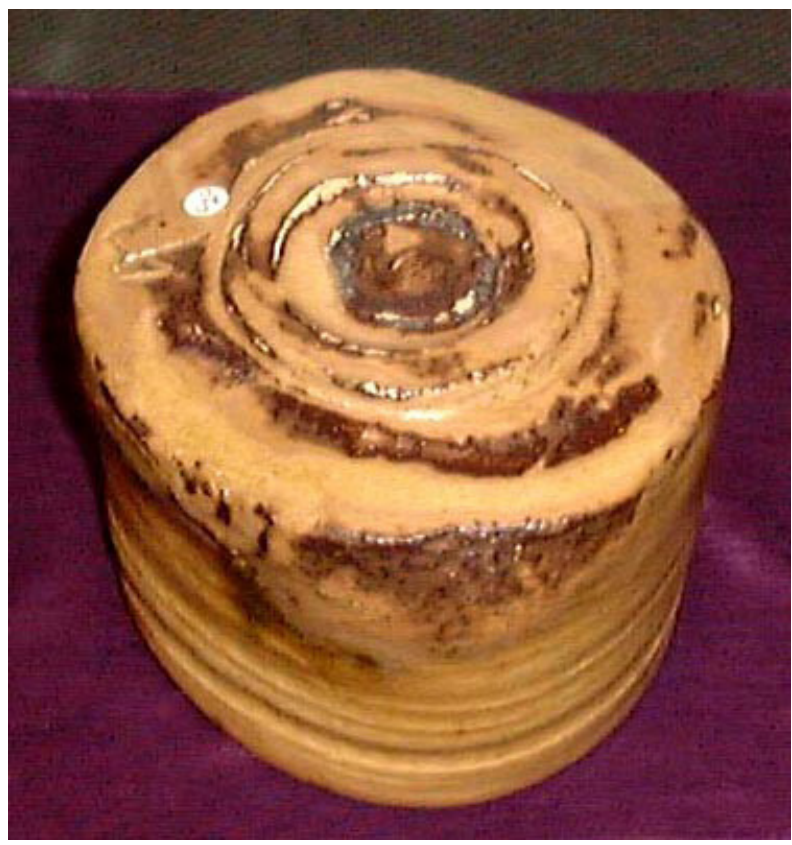

Ki-Seto Piece. Author: Kagami Shukai. Ceramic. Late 16th century. Ownership: Mino Potter Kato Kozo's home

tic of specific periods, stylistic and technical features of ceramics produced in different workshops and localities, distribution of paint in paintings and glazes, shapes and proportions, as well as a comparison of the bottom of the product with known samples identified as genuine. The latter analysis technique is used since masters, when counterfeiting ceramics, are often guided by photographs from museum catalogs and/or by fragments of vessels; however, they often do not see its bottom and, therefore, cannot copy it [Collecting Guide, 2020].

Chemical/spectral analysis, and analysis of seals, which is considered relatively unreliable since it is easy to fake them, are used.

Thus, there are several different techniques of analysis. Since most of them are not self-sufficient ways to determine authenticity, a combination of different methods is needed, if possible - a consultation with several experts. However, the ever-evolving market for fakes necessitates the creation of more technically advanced and accurate analysis, attribution, and identification of authenticity techniques.

These days, cultural dominance plays an increasing role in the reproduction of neo-colonial politics. As a result, in third-world countries, the population's poverty level is growing, and alienation and emasculation of the local intelligentsia occur. Therefore, a large number of works still remain unknown.

The following methods are used to identify the authenticity of objects: verification of provenance, 


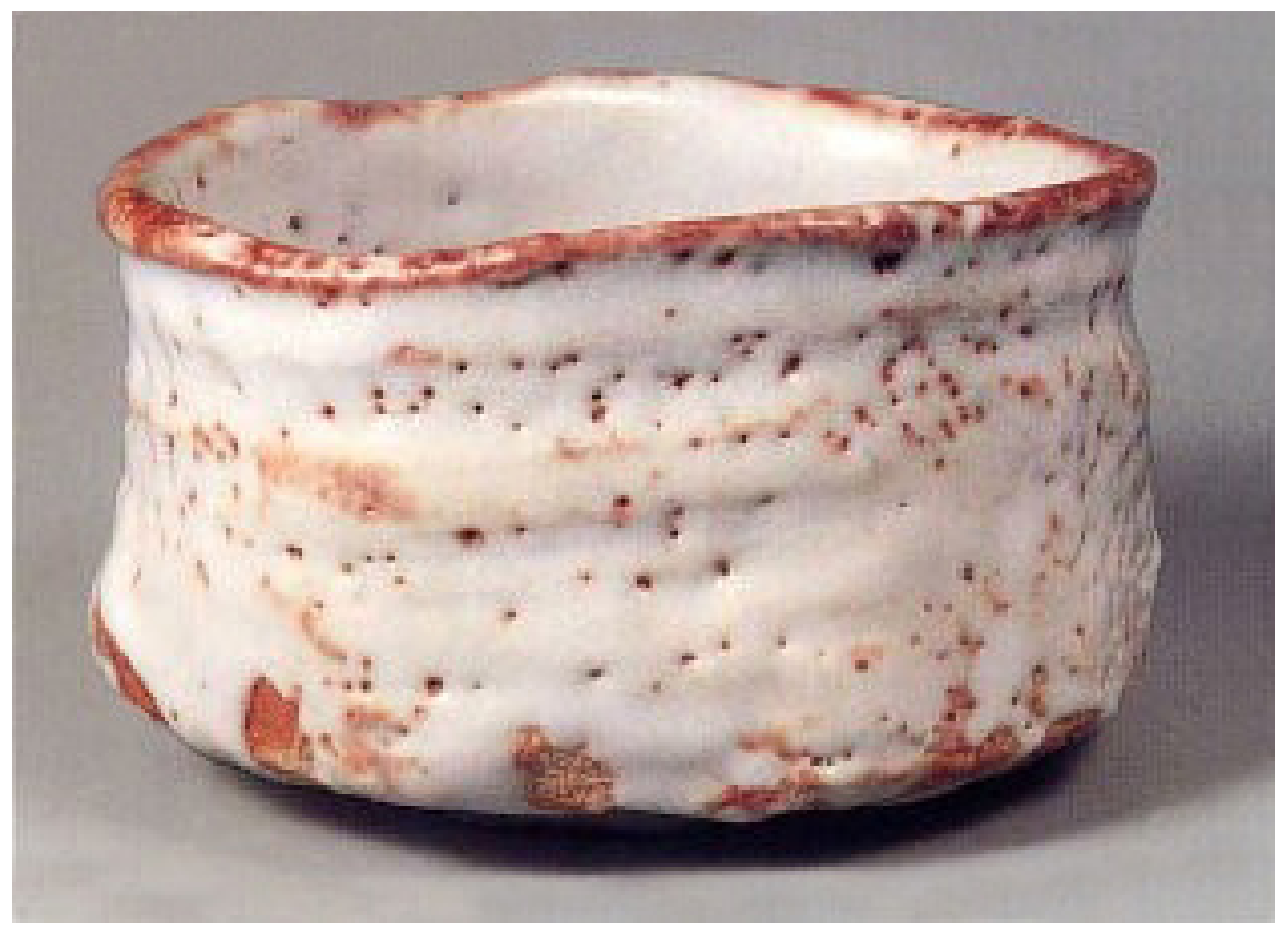

Sake Vessel. Author: Kato Tokuro. Ceramic. Late 1937

comparison of ceramic samples by weight and tactile indicators, shade and glaze analysis, stylistic and technical features, distribution of paint in paintings and glazes, shapes and proportions, as well as a comparison of the bottom of the product with known samples identified as genuine.

It is worth noting that there is a lack of a transparent system for determining an artwork's authenticity. Being very rough, modern attributions techniques leave significant room for error. The complexity of the examination and, in several cases, the lack of a clear set of criteria for the authenticity of the ceramics and the growing commercial value of a number of categories of pottery products promote market growth of high-quality counterfeits. Often, as is the case with Kato Tokuro's works, the line between a fake and an artwork is blurred. It is especially true for Asian ceramics due to the extremely respectful attitude of the masters to the art of previous eras and their careful study. Therefore, there are no typical signs of authentic pottery due to the individuality of each exhibit.

\section{REFERENCES}

1. The Art Newspaper. 02 (81). March, 2020. p. 10. (in Russian)

2. Chistie's. Asobi. London, 2014 (in English)

3. Franks, A.W. 1880. Japanese Pottery: Being a Native Report 1826-1897, South Kensington Museum. London (in English)

4. Seton, A. 2004. Collecting Japanese Antiques (in English)
5. Kato Tokuro [Web resource] http://www.e-yakimono. net/html/kato-tokuro-jt.html (in English)

6. "An Appreciation of Porcelain in Four Objects", The Economist. December 18, 2018. https://www.economist. com/christmas-specials/2018/12/18/an-appreciationof-porcelain-in-four-objects (in English)

7. Collecting guide: 10 Things you Need to Know about Chinese Ceramics // Christie's, March 31, 2020 https:// 
www.christies.com/features/Chinese-Ceramics-Collecting-Guide-7224-1.aspx (in English)

8. Pomfret, J. 2008. "Fake Chinese Ceramics Cast Shadow over Art Boom", Reuters, August, 6 https://www. reuters.com/article/us-china-ceramics-fakes/fake-chinese-ceramics-cast-shadow-over-art-boom-idUSHKG34085820080806 (in English)

9. Chao, S. 2015. "Can you spot a fake antique? China's forged antiques market is booming as the country's burgeoning mega-rich unknowingly buy them up", Al-Jazeera, November, 27 https://www. aljazeera. com/programmes/101east/2015/11/china-fake-antique-151126124236089. html (in English)

10. F.R. What Makes a Work of Art Valuable, The Economist, January 6, 2017. https://www.economist.com/theeconomist-explains/2017/01/06/what-makes-a-workof-art-valuable (in English)

11. Fleming, S.J. 1972. "Thermoluminescence Authenticity Testing of Ancient Ceramics Using Radiation-sensitivity Changes in Quartz", Naturwissenschaften, no. 59, no. 4, pp. 145-151 DOI: https://doi.org/10.1007/ BF00637352 (in English)

12. Hiro Izushi. 2010. "Conflict Between Two Industrial Networks: Technological Adaptation and Inter-firm Relationships in the Ceramics Industry in Seto, Japan", Regional Studies, Taylor \& Francis, vol. 31, no. 2, pp. 117129, DOI: https://doi.org/10.1080/00343409750133242 (in English)

13. Kota Maruya, Sampei Yamashita, Tadashi Uchiyama. 2015. "Community Spaces in the Minds of Traditional
Craftsmen in a Pottery Village in Japan", Frontiers of Architectural Research, vol. 4, no. 4, DOI: https://doi. org/10.1016/j.foar.2015.05.002. (in English)

14. Moeran, B. 1990. "Japanese Ceramics and the Discourse of 'Tradition'", Journal of Design History, no. 3. pp. 213-225. DOI: https://doi.org/10.1093/jdh/3.4.213 (in English)

15. Moeran, B. 1987. "The Art World of Contemporary Japanese Ceramics", Journal of Japanese Studies, vol. 13, no. 1, pp. 27-50. DOI: https://doi.org/10.2307/132585 (in English)

16. Liritzis, I. et al. 2013. "Luminescence-Based Authenticity Testing. In: Luminescence Dating in Archaeology, Anthropology, and Geoarchaeology", Springer Briefs in Earth System Sciences. Springer, Heidelberg. DOI: https://doi.org/10.1007/978-3-319-00170-8_5 (in English)

17. Stark, M.T. 2003. "Current Issues in Ceramic Ethnoarchaeology", Journal of Archaeological Research, no. 11, pp. 193-242 DOI: https://doi. org/10.1023/A:1025079730891 (in English)

18. Dictionary of Fine Art Terms [Web resource] http:// www.artdic.ru (in Russian)

19. Mironov, A.M. 2010. Istoriya antichnogo iskusstva [The History of Ancient Art], Moscow: Librokom, p. 304. (in Russian)

20. Voshchinina, A.I. 1962. Antichnoye iskusstvo: istoricheskiy ocherk [Antique Art: A Historical Sketch], Moscow: Publishing house of the USSR Academy of Arts, p. 396. (in Russian) 
Жанна Игоревна Полански

Санкт-Петербургский государственный институт культуры

e-mail: 7216631@mail.ru

Москва, Россия

ORCID 0000-0001-7316-4135

\section{ТРАДИЦИИ ЯПОНСКОЙ КЕРАМИКИ}

Аннотация: Статья посвящена важной теме - традициям японской керамики. Её актуальность состоит в важности решения проблемы идентификации произведений искусства: являются ли они подделкой или оригиналом. Неправильная атрибуция объекта может повлечь тяжёлые юридические и материальные последствия, а также сильно повлиять на репутацию. Выявлены различия между терминами «копия» и «подделка» с оценкой положительных и отрицательных сторон фальсификации. Для идентификации и атрибуции искусства необходимы специалисты, имеющие высокую квалификацию, подтверждённую сертификатами и дипломами. В статье раскрыты основные требования, которыми должны они обладать. Также выделяются и описываются характерные особенности и основная проблема западного искусства, описана идеология европоцентризма, согласно которой Европа, или Запад, является высшей ступенью развития человеческой цивилизации, а весь остальной мир считается примитивным и отсталым. В данной статье представлен яркий пример ошибки идентификации произведения искусства - скульптуры «Голова с рогами» Музеем Гетти, а также ряд случаев создания грандиозных мировых подделок в искусстве японской керамики. Изучены труды таких авторов, как Като Токуро, художника по керамике, работы которого удостоились высшей ху-

Проблемы подделок для музеев, частных коллекционеров и галерей сложно переоценить. По разным оценкам, от 30 до 60\% международного рынка произведений искусства - это подделки. Зачастую от правильного определения подлинности экспоната зависит репутация множества экспертов. Неправильная атрибуция произведения искусства может повлечь тяжёлые юридические и материальные последствия для одной или нескольких сторон.

В ходе написания работы использовались методы сравнительно-исторического анализа, дожественной награды в Японии и получили широкое признание среди коллекционеров и кураторов Запада, Кагами Шукай и Като Кодзю. Раскрыта керамическая традиция Сето и её значение для общекультурного искусства. Она была создана великим Като Широдзаемон и получила своё название по наименованию города в Японии, который славится своим гончарным делом. В статье показана важность традиционных методов в японской керамической истории искусства. Отсюда проистекает стремление мастеров следовать старинным образцам и техникам. Также в данной статье описаны особенности и раскрыты различия между традиционной и студийной керамикой. Изучены особенности азиатского подхода, который направлен на воспроизведение культурных ценностей в неизменном виде, параллельно с развитием прогресса в других областях деятельности. Основная задача данной статьи - научить выявлять явную подделку путём разбора характерных признаков подлинных керамических изделий. Для этого дан значительный анализ характерных особенностей аутентичных керамических изделий, представлен ряд методик и методов определения подлинности экспоната.

Ключевые слова: фальсификация, копия, керамика, керамическая традиция Сето, жёлтый Сето, японская керамическая традиция, подделка, оценка изделий.

типологического описания рассматриваемого явления. И аксиологический метод, позволяющий раскрыть ценностные ориентиры, задаваемые личности искусством. Также используется конкретно-исторический анализ, описание конкретных фактов с их последующим теоретическим осмыслением. Проведено сопоставление философско-эстетических, культурологических, искусствоведческих, психологических аспектов данного явления.

Несмотря на то, что современное культурное господство Запада в странах третьего мира - это 
составная часть и один из ключевых аспектов неоколониализма, который одновременно с этим в наши дни существует в составе так называемых многорасовых обществ Запада, концепция такого доминирования была сформирована задолго до появления многонациональных государств. Её появление совпадает с началом Нового времени на Западе, когда она парадоксальным образом стала частью западной «гуманистической» концепции мироустройства. Позднее этот парадокс был как будто бы разрешён, по крайней мере на теоретическом уровне, Марксом с его историческим материализмом и диалектической теорией освобождения, однако мессианская задача европейской «гуманистической» традиции по окультуриванию всего остального мира по-прежнему в ходу. Идеология европоцентризма, согласно которой Европа, или Запад, является высшей ступенью развития человеческой цивилизации, а весь остальной мир считается примитивным и отсталым, задаёт иерархическую пирамидальную структуру мира, в которой и человеческая, и природная энергия движется наверх и собирается на самой верхушке пирамиды.

Западное искусство популяризуется по всему миру как часть идеологии, согласно которой искусство не зависит от социо-экономических и политических условий того или иного народа. Искусство может создаваться где угодно (то есть в Европе) парочкой «гениев», а потреблять его будут все остальные народы мира.

Существует явная проблема для искусства на Западе, а именно: чистое искусство тут под запретом. Поэтому большое количество произведений так и остаются неизвестными, так как в момент озарения создатель искусства не думает о толерантности, расовых и религиозных предрассудках и соблюдении пропорциональности в гендерном разнообразии.

Рассматриваемая в этой статье тема основывается на понятиях «копия» и «подделка» в искусстве, их положительном и отрицательном влиянии на цивилизацию. Согласно словарю копия - «это копирование оригинала, исполненное самим автором либо другим художником. Копия может отличаться от оригинала по технике и размерам, но, в отличие от реплики, должна точно воспроизводить манеру и композицию оригинала» [Словарь терминов изобразительного искусства]. В большинстве случаев копируются материалы в целях обучения (получения навыка), но возмож- ны и авторские копии - для продаж. Цель подделки - извлечение выгоды путём обмана.

Многие тысячелетия назад люди делали первые шаги на пути искусства, ведь даже в самых суровых условиях человек нуждался в красоте [Миронов А.М. С. 61].

Первыми создателями бесчисленных копий были древние римляне [Вощинина А.И. С. 352].

Стоит отметить, что для идентификации и атрибуции искусства необходимы специалисты, имеющие высокую квалификацию, подтверждённую сертификатами и дипломами. Найти таких специалистов, а особенно в определённых местностях Азии и Океании, является затруднительным. А также местные особенности искусств и ремёсел Запада очень специфичны, и данная область достаточно ограничена, что затрудняет идентификацию и может привести к приобретению подделок в качестве экспонатов ведущими музеями.

Недавний пример наблюдался, когда Музей Гетти приобрёл скульптуру «Голова с рогами», которую сначала приписывали авторству Гогена, а затем к местному искусству полинезийских мастеров. В результате вторая версия была опровергнута полинезийскими искусствоведами, в силу нехарактерности данного произведения для местных художественных традиций, а версия с авторством Гогена была исключена за счёт соотнесения произведения с современными Гогену фотоисточниками. Точная сумма ущерба, понесённого музеем, неизвестна, так как подробности сделки не оглашались, но, по инсайдерской информации, убытки Музея Гетти от неправильной идентификации составили \$3-5 млн. [The Art Newspaper, 2020, с. 10.].

Далее рассмотрим подобные случаи касательно японской керамики.

Одним из самых громких скандалов в истории атрибуции старинной керамики связан с именем Като Токуро, художника по керамике, работы которого удостоились высшей художественной награды в Японии и получили широкое признание среди коллекционеров и кураторов Запада. В частности, они были представлены на выставках в Metropolitan Museum of Art и Универмага Сейбу, а также на аукционе Christie's [Asobi, 2014, p. 46]. Творчеству Като посвящён целый Мемориальный музей Суйсэн Тогэй в Нагое.

«Когда вы выставляете свою работу на всеобщее обозрение, вы получаете язвительную 
критику. Именно тогда вы становитесь зрелым человеком», - считал Като.

Като Токуро унаследовал ремесло своей семьи. Традиции мастерства передавались из поколения в поколение семьи Токуро. Более того, Токуро родился и вырос в местности, особенно богатой гончарными традициями в Японии, - а именно, в городе Сето. Название населённого пункта дало имя одноимённой традиции японской керамики, так как в Сето была расположена одна из «Шести древних печей для обжига». Эти шесть мест дали начало основным традициям японской керамики.

Традиция изготовления керамических изделий Сето восходит к XIII веку. Като Широдзаемон привез технологию изготовления данного вида керамики из Китая и впоследствии после нескольєких неудачных попыток обосноваться в разных частях Японии основал керамическую мастерскую в Сето. Керамика, которую он изготавливал, получила название Ко-Сето [Franks, 1880, р. 29].

Като Широдзаемон прославился, несмотря на попытки изготавливать фарфор, за счёт каменной керамики, изготавливаемой при высоких температурах, известной под названием Иши-яки.

Като Широдзаемон передал традиции изготовления керамики своим потомкам, и его семья жила и изготовляла керамику под его именем в течение четырёх поколений. Традиция изготовления керамики Сето передавалась среди мастеров в течение нескольких веков.

Данная разновидность керамики названа «Сето» по имени территории к северу от Нагои. Термин «setomono» - «вещь из Сето» является синонимом фарфора в японском языке. Однако регион Сето изготовлял множество разновидностей керамики, помимо фарфора.

Разновидность керамики Сето является центральной для японской традиции данного вида искусства и активно осознаётся самими японцами как таковая. Это отражается в названии «kuniyaki» - «национальные изделия», часто применяемом к керамической продукции региона [Seton, 2004].

Данный регион традиционно изготовляет посуду для чайной церемонии, что дополнительно повышает важность Сето для японской не только керамической, но и общекультурной традиции.

Тесно связана с чайной церемонией производимая в той же местности керамика ки-сето (жёлтый сето) (см. Приложение 1). Начало традиции ки-сето было положено в XV в. мастером Хукуан, который основал производства ки-сето - грубой посуды характерного жёлтого оттенка (см. Приложение 1). Большая часть керамики ки-сето изготавливалась недалеко от горы Санаге.

По некоторым классификациям, ки-сето относят к керамике Mino, несмотря на то, что та производилась не в Сето, а в городе Таджими-мура (Таджими) смежного с местностью Аичи, где расположен город Сето. Однако, согласно наиболее распространённому мнению, именно город Сето и окрестности с самого начала являлись традиционным местом производства ки-сето.

В своей книге «Желтый Сето» Като Токуро поставил под сомнение эту общепринятую теорию. Он утверждал, что ки-сето относится к керамике мино [Seton, 2004] и, соответственно, производилась в городе Таджими [Tokuro, 2020]. Также Токуро критиковал необоснованное почитание традиции. Книга вызвала скандал и многие её экземпляры были сожжены поборниками традиции и националистами.

Несмотря на революционные, по меркам Японии 1930-х гг. идеи, Като Токуро продолжал работать в рамках традиционной керамики. Так, изготовленную им плошку «Недзуми-шино чаван» сравнивали с лучшими образцами керамики периода Монояма (конец XVI - начало XVII в.) и рассматривали как возрождение традиции керамики шино [Asobi, 2014, p. 46], изготавливавшейся в местности Мино в конце XVI века. Характерно, что до того, как изготовить данное изделие, Като Токуро много лет изучал старинные образцы керамики Мино, чтобы быть способным в точности воспроизвести технологию и оформление.

Като Токуро гордился своей способностью создавать керамику, неотличимую от древних образцов даже для экспертов. В 1937 году Токуро изготовил несколько копий сосуда для саке периода Эйнин (1293-1299). По другой версии их изготовил его сын Окабе Минео. Позднее гончар разбил их и закопал рядом с местом расположения одной из древних печей для обжига керамики. В начале 1960-х годов осколки были обнаружены в ходе археологических раскопок. Известный специалист по керамике Фуджио Кояма идентифицировал осколки как представляющие значительную культурную ценность и предложил дать им официальный статус Важной Культурной Ценности. Нужно отметить, что Фуджио Кояма был дружен с Като Токура, но не знал о проделке дру- 
га. Когда Като Токура сознался в том, что сделал, оба они были дискредитированы и вынуждены подать в отставку. В результате скандала репутация Токуро была разрушена и так никогда до конца и не восстановилась после понесённого урона. Так, даже когда изделия Токуро (см. Приложение 2) были причислены к национальному достоянию, статус национального достояния не был распространён на самого Токуро, как этого удостаивались наиболее видные художники по керамике Японии XX-XXI вв.

Таким образом, можно отметить высокую важность традиционных методов в японской керамической истории искусства. Отсюда проистекает стремление мастеров следовать старинным образцам и традиционным техникам. Особенно чётко эта тенденция прослеживается среди представителей семей, веками специализирующихся на изготовлении керамики. Отсюда проистекают несколько основных следствий.

Во-первых, наблюдается непрерывность и практическая неизменность традиции в течение веков, высокая степень преемственности художественной традиции [Seton, 2004]. В отличие от так называемой студийной керамики, где приветствуется новаторство и подчёркивание личности автора, керамика традиционная особенно изготовляемая в деревнях и древних городских центрах производства - изготавливается с доскональным соблюдением сохранившихся традиционных технологий [Seton, 2004]. Если какая-то технология оказывается утеряна, мастера готовы затратить значительное время и усилия на изучение и восстановление технологии в её традиционном виде. Характерно, что мастера специализирующиеся на подделке керамики, составляют значительную часть аудитории дилеров, торгующих осколками керамики имперского периода в Китае [An appreciation of porcelain in four objects, 2018].

Таким образом, традиция ценится выше новации, а древность и максимальная неизменность технологии являются самоценностью. Данная особенность соответствует общей направленности азиатского подхода на воспроизведение культурных ценностей, в широком смысле, в неизменном виде, параллельно с развитием прогресса в других областях деятельности.

Для японской керамики, как и для многих искусств и ремёсел Азии, характерно отсутствие подчёркивания личности художника. Напротив, подчёркиваются традиция и анонимность [Seton, 2004]. Клеймо, подпись или индивидуальные штрихи, являющиеся своеобразной подписью автора, далеко не всегда можно найти на произведениях японских или китайских мастеров. Таким образом, отношение азиатских мастеров к авторству зачастую отличается от характерного для более индивидуалистических культур. Так, в Японии и, в том числе, в Сето сельская керамика традиционно анонимна [Asobi, 2014, p. 105].

Зачастую у работающих в рамках традиции авторов отсутствует стремление к обозначению собственного авторства. Подобная деиндивидуализация произведений искусства создаюёт дополнительную сложность идентификации и атрибуции. Субъективность экспертного мнения, и зачастую отсутствие возможности произвести атрибуцию со стопроцентной точностью составляют другую сторону проблемы.

Более того, возникают сложности и при оценке изделий, так как ценность сильно варьируется в зависимости от авторства. Отсюда возникают дополнительные сложности для коллекционеров, аукционных домов и частных галерей при оценке произведений искусства с обозначенным авторством. Неправильная оценка ценности, категорийной принадлежности и/или авторства керамики может повлечь за собой компенсации, судебные процессы, репутационные последствия, снижение доверия к дилерам, экспертам-оценщикам и отдельным коллекционерам, выставляющим предметы искусства на продажу или предоставляющим их для временных экспозиций.

Другим следствием досконального следования традиции является повышенная возможность подделок. Подделки в Азии не обязательно носят утилитарный характер. Так, эксперты аукциона Christie's отмечают, что зачастую подделки создаются из почтения к традиции [Collecting guide, 2020].

Так, когда китайский миллиардер и коллекционер Лю Ицянь купил «Куриную чашу» XV века за рекордные \$36 млн. на аукционе Sotheby's, его супруга Ван Вей, работающая куратором в музее, получила 10000 высококачественных копий шедевра в дар от Сян Юанхуа, владельца мастерской в городе Цзиндэчжэнь провинции Цзянси, специализирующейся на подделке керамики [An appreciation of porcelain in four objects, 2019].

Древние произведения считаются непревзойдёнными по качеству и технике исполнения. 
Многие мастера тщательно изучают мельчайшие нюансы старинной керамики, а древность и традиция сообщают изделию особенную ценность при продаже. Таким образом, неизбежно появление на рынке высококачественных имитаций старинных изделий.

Так, например, в Китае существует значительное количество мастерских, специализирующихся на высококачественных подделках китайского фарфора династии Мин и Цин [Pomfret, 2008]. Например, одна из специализаций керамических мастерских в вышеупомянутом городе Цзиндэчжэнь провинции Цзянси - подделка керамики Мин и Цин. Так как крупные аукционы используют провенанс - происхождение и отслеживание непрерывности цепочки владельцев произведения искусства от создания до поступления на аукцион - в качестве одного из основных критериев определения подлинности, часто такие изделия попадают на рынок через небольшие аукционы, которые проводят проверки менее тщательно [Chao, n.d.].

Впоследствии такая керамика может, пройдя через руки ряда коллекционеров и экспертов, попасть в более крупные аукционные дома, крупные и уважаемые частные коллекции и даже на выставки [F.R. What makes a work of art valuable, 2017].

Притом в Азии существует долгая традиция подделки керамики. Например, керамика периода Мин (1368-1644 гг.) высоко ценится коллекционерами на протяжении нескольких веков. Как следствие, уже при династии Цин (1644-1912 гг.) мастера подделывали и саму керамику, и клейма периода Мин на ней [An appreciation of porcelain in four objects, 2018].

Таким образом, подобные изделия могут быть трудноотличимы от оригинальных произведений периода и/или мастера не только для покупателей и коллекционеров, но и для оценщиков, экспертов по декоративно-прикладному искусству определённого периода, галеристов и пр.

Применяются следующие методики определения подлинности экспоната: проверка провенанса, сравнение образцов керамики по весу и тактильным показателям, анализ оттенков и глазури, характерных для тех или иных периодов, стилистических и технических особенностей керамики, произведённой в разных мастерских и местностях, распределение краски в росписях и глазури, формы и пропорции, а также сравне- ние донышка изделия с известными образцами, идентифицированными как подлинные. Последняя техника анализа используется, так как при подделке керамики мастера часто ориентируются на фотографии из музейных каталогов и/или на осколки сосудов, но часто не имеют перед глазами донышка и, значит, не могут его скопировать [Collecting guide, 2020].

Также используется химический/спектральный анализ, анализ клейм, считающийся относительно ненадёжным из-за лёгкости их подделки.

Таким образом, существует целый ряд различных методик анализа. Так как большинство из них не является самодостаточными способами определения подлинности, необходимо сочетание разных методов, по возможности - консультация с несколькими экспертами. Тем не менее, постоянно развивающийся рынок подделок обуславливает необходимость создания более технически продвинутых и точных методик анализа, атрибуции и определения подлинности.

В наши дни культурное доминирование играет всё возрастающую роль в воспроизведении неоколониальной политики, в результате в странах третьего мира растёт уровень бедности простого населения и происходит отчуждение и выхолащивание местной интеллигенции. Поэтому большое количество произведений так и остается неизвестными.

Для выявления подлинности объектов используются следующие методы: проверка провенанса, сравнение образцов по весу и тактильным показателям, анализ оттенков и глазури, стилистических и технических особенностей, способов распределения краски в росписях и глазури, формы и пропорции, а также сравнение донышка изделия с известными образцами, идентифицированными как подлинные.

Стоит отметить отсутствие чёткой системы определения подлинности произведений искусства. Современные методики атрибуции оставляют достаточно значительный простор для ошибки, будучи весьма приблизительными. Сложность экспертизы, и, в ряде случаев, отсутствие чёткого набора критериев подлинности изделия керамики, а также растущая коммерческая ценность ряда категорий произведений керамики способствуют росту рынка высококачественных подделок. Зачастую, как в случае с изделиями Като Токуро, грань между подделкой и произведением искусствуа размывается. Особенно это характерно 
для азиатских изделий керамики, в силу крайне почтительного отношения мастеров к искусству предыдущих эпох и тщательному их изучению.
Поэтому из-за индивидуальности каждого экспоната не существует общих признаков подлинных керамических изделий.

\section{БИБЛИОГРАФИЯ}

1. The Art Newspaper. - 02 (81). - Март 2020 г. - C. 10.

2. Chistie's. Asobi. London, 2014 [Электронный ресурc]. -https://www.christies.com/PDF/ catalog/2014 /KEN5546_SaleCat.pdf

3. Franks A.W. Japanese pottery: being a native report 1826-1897 / South Kensington Museum. London, 1880.

4. Seton A. Collecting Japanese antiques [Электронное издание]. - 2004.

5. Kato Tokuro [Электронный ресурс]. - http:// www.e-yakimono.net/html/kato-tokuro-jt.html

6. An appreciation of porcelain in four objects // The Economist. -December 18, 2018. - https:// www.economist.com/christmas-specials/2018/12/18/ an-appreciation-of-porcelain-in-four-objects

7. Collecting guide: 10 things you need to know about Chinese ceramics // Christie's. - March 31, 2020. -https://www.christies.com/features/Chinese-Ceramics-Collecting-Guide-7224-1.aspx

8. Pomfret J. Fake Chinese ceramics cast shadow over art boom // Reuters. - August 6, 2008. - https://www.reuters.com/article/us-china-ceramics-fakes/fake-chinese-ceramics-cast-shadow-overart-boom-idUSHKG34085820080806

9. Chao S. Can you spot a fake antique? China's forged antiques market is booming as the country's burgeoning mega-rich unknowingly buy them up // Al-Jazeera. - November 27, 2015. - https://www. aljazeera.com/programmes/101east/2015/11/china-fake-antique-151126124236089. html

10. F.R. What makes a work of art valuable // The Economist. - January 6, 2017. - https://www.economist.com/the-economist-explains/2017/01/06/whatmakes-a-work-of-art-valuable

11. Fleming, S.J. (1972) Thermoluminescence authenticity testing of ancient ceramics using radiation-sensitivity changes in quartz. - Naturwissenschaften 59, 145-151 DOI: https://doi.org/10.1007/ BF00637352
12. Hiro Izushi (2010) Conflict Between Two Industrial Networks: Technological Adaptation and Interfirm Relationships in the Ceramics Industry in Seto, Japan, Regional Studies, Taylor \& Francis 31:2,117-129, DOI: https://doi.org/10.1080/00343409750133242

13. Kota Maruya, Sampei Yamashita, Tadashi Uchiyama (2015) Community spaces in the minds of traditional craftsmen in a pottery village in Japan. - Frontiers of Architectural Research. - Volume 4, Issue 4, DOI: https://doi.org/10.1016/j.foar.2015.05.002

14. Moeran B. (1990). Japanese Ceramics and the Discourse of 'Tradition'. - Journal of Design History. 3. 213-225. DOI: https://doi.org/10.1093/jdh/3.4.213

15. Moeran, B. (1987). The Art World of Contemporary Japanese Ceramics. - Journal of Japanese Studies. - 13,1 27-50. DOI: https://doi. org/10.2307/132585

16. Liritzis I. et al. (2013) Luminescence-Based Authenticity Testing. In: Luminescence Dating in Archaeology, Anthropology, and Geoarchaeology. Springer Briefs in Earth System Sciences. Springer. - Heidelberg. DOI: https://doi.org/10.1007/978-3319-00170-8_5

17. Stark M.T. (2003). Current Issues in Ceramic Ethnoarchaeology. - Journal of Archaeological Research. - 11, 193-242 DOI: https://doi. org/10.1023/A:1025079730891

18. Словарь терминов изобразительного искусства [Электронный ресурс]. - http://www.artdic. ru/txt/10/0488.htm

19. Миронов А.М. История античного искусства. - М.: Либроком, 2010. - 304 с.

20. Вощинина А.И. Античное искусство: исторический очерк. -М.: Изд-во Академии художеств CCСР, 1962. - 396 c. 